\title{
La Memoria Sumergida 1
}

\author{
The Submerged Memory
}

Ricardo MELGAR BA02

Instituto Nacional de Antropología e Historia (INAH), México.

\section{Resumen}

En este artículo, Ricardo Melgar Bao analiza el fenómeno de las guerrillas latinoamericanas desde distintos puntos de vista. En primer lugar, compulsa las definiciones del concepto guerrilla con su materialización en el continente, incorporando también el concepto de terror en la discusión. Luego se enfoca en la violencia, recuperando elaboraciones teóricas y el modo en que es resignificada por los movimientos guerrilleros. Finalmente, explora los sentidos que adquiere la muerte, el martirologio y la lógica sacrificial en los diferentes espacios que la guerrilla ocupó en América Latina.

Palabras clave: guerrilla; violencia; izquierdas; Guerra Fría; América Latina.

\begin{abstract}
In this article, Ricardo Melgar Bao analyzes the phenomenon of Latin American guerrillas from different points of view. In the first place, he conpares the definitions of the guerrilla concept with its materialization on the continent, also incorporating the concept of terror in the discussion. Then he focuses on violence, recovering theoretical elaborations and the way in which it is resignified by the guerrilla movements. Finally, he explores the meanings that death, martyrology and sacrificial logic acquire in the different spaces that the guerrillas reached in Latin America.
\end{abstract}

Keywords: Guerrilla; Violence; Left; Cold War; Latin America.

\footnotetext{
1 Este artículo apareció originalmente en la revista Memoria de Ciudad de México, en los números 164 y 165, correspondientes a octubre y noviembre de 2002. Agradecemos a Memoria por permitirnos su republicación.

2 Ricardo Melgar Bao (Lima, 1946-Cuernavaca, México, 2020): Historiador y antropólogo peruano, doctor en Estudios Latinoamericanos por la UNAM. El autor agradece los comentarios críticos de Ross Gandy, Juan José García, Salvador Morales, Morgan Quero y Arturo Taracena, así como las ayudas 


\section{Sacralización de la violencia en las guerrillas latinoamericanas}

Resulta preocupante que la XXIV Conferencia de Ejércitos Americanos 20002001 sostenga que vivimos un tiempo de emergencia de "conflictos de mayor envergadura" que los experimentados en los decenios precedentes en la región, en los cuales el tema de la guerrilla aparece confundido con el terrorismo (Ejército de Chile, 2000: 1). Además, los estudiosos de las guerrillas latinoamericanas confrontan el peso -entre otros- de los relatos ideológicos surgidos de la Guerra Fría. Estos han marcado la mayoría de las investigaciones realizadas a través de la visión conspirativa sobre la siniestra mano roja internacional, así como bajo la práctica hagiográfica sobre los héroes guerrilleros o la muy pedagógica historia-tradición de las guerrillas. Esta historia por rearmar resiente también el tenor restrictivo del acceso a las fuentes mismas, en su mayoría evasivas, sumergidas, facciosas, fabricadas y además dispersas, dentro y fuera del país o el continente.

A lo largo del artículo, abriremos dos ventanas hacia el universo guerrillero a partir de los referentes de violencia y guerrilla, así como sobre los saberes especializados acerca de los conflictos armados legados por la Guerra Fría. La primera entrada reseñará críticamente el contexto de las principales tendencias que filian las investigaciones sobre las guerrillas latinoamericanas. La segunda explorará los sentidos de la violencia en la nueva izquierda bajo los marcos de la Guerra Fría, más que los que emergieron de las tradiciones regionales.

\subsection{El mirador académico: fragmentación del saber o razón oblicua}

Si la categoría reaganiana del terrorismo en los últimos veinte años ha venido opacando el sentido de la guerrilla latinoamericana, lo ha logrado por sobredimensionar uno de sus atributos tácticos aleatorios; tal juego metónico que ha sido vulgarizado mediáticamente debe ser puesto entre paréntesis y criticado, partiendo de otras entradas y lecturas. Debe preocuparnos cómo el uso polisémico del terrorismo ha echado raíces en nuestra más reciente historiografía sobre las guerrillas en América Latina y en otros continentes. En otras palabras, estamos a favor de la pertinencia de analizar el terror como táctica guerrillera real a condición de no sobregeneralizar su práctica ni obviar que su referente de sentido más fuerte e históricamente recurrente emerge del terrorismo estatal y en menor medida de algunas tradiciones de la violencia y crueldad local o regional.

Si la guerrilla tiene un sentido acotado en las categorías más amplias de la violencia política y la revolución, habrá que referir ese sentido explícitamente, apoyándonos en una lectura crítica de los diccionarios de la lengua y de las ciencias

bibliográficas brindadas por Ezequiel Maldonado, Francisco Amezcua, Eduardo Sandoval y Gregorio Sosensky. 
sociales más usados en nuestros medios académicos. La historia del propio término y su inserción en el habla popular castellana nos remiten al decir de una opinión autorizada, más a principios del siglo XIX que al contexto del siglo XVI, al desglosar el sentido de guerrillero del de guerrilla (Corominas, 1983: 309; RAE, 2001: 11741175)3. De otro lado, en el habla popular hay muchos términos vernáculos que reelaboran contradictoriamente los términos de guerrilla y guerrillero y que están asociados a ciertos relatos populares; unos y otros deben ser tomados en cuenta para alcanzar una aproximación a las adscripciones de la identidad guerrillera en los imaginarios sociales. En Cuba, el término guerrillero, decía el Che, tenía "un significado repulsivo", es decir, poseía el estigma de su indeseable filiación colonialista, el cual tuvo que ser resemantizado a partir de la Revolución Cubana (Guevara, 1985). Lo que debe quedar en claro es que el terreno de su conceptuación está minado y que hay que caminar con cuidado.

El historiador Carlos M. Rama, conceptuando a la guerrilla para El Diccionario UNESCO de Ciencias Sociales, dice que la adhesión a la guerrilla es espontánea y voluntaria, lo cual no resulta muy convincente a la luz de la experiencia latinoamericana de los últimos veinte años, pero sí es sugerente su afirmación de que la guerrilla "se caracteriza por la acción bélica de formaciones de escasa entidad, autónomas en su movimiento y jerarquía funcional, especializadas en emboscadas, asaltos de sorpresa y breves combates" (Rama, 1988, II: 979). Sin embargo, esta definición omite el referente político y simbólico, significando a la guerrilla desde su accionar militar operativo. Nos parece algo mejor, salvo por el excesivo peso definitorio del combate, la definición ofertada por Fulvio Attiná para el Diccionario de Política coordinado por Norberto Bobbio y Nicola Mateucci, quien prefiere consignar que "la guerrilla es un tipo de combate que se caracteriza por el encuentro entre formaciones irregulares de combatientes y un ejército regular. Los objetivos que con ésta se persiguen son más políticos que militares" (Attina, 1981, A-J: 769). La combinación de los fines políticos y militares en la acción guerrillera no es ajena a sus marcas culturales, por ello, la guerrilla nos obliga a ensanchar su universo de sentido. Si la táctica aleatoria del terror supone la construcción del miedo paralizante en el imaginario del enemigo, ésta se logra gracias a la eficacia simbólica de una usualmente sorpresiva acción aniquiladora ejemplar y/o una potencial amenaza de exterminio. Esta práctica, sin lugar a dudas, es más recurrente desde el campo contrainsurgente que desde el propio accionar guerrillero; en todo caso, exhibe en lo general una bidireccionalidad asimétrica de impacto variable en la depredación de vidas humanas, además de sus costos psicoculturales. Al respecto,

\footnotetext{
${ }^{3}$ Los cinco sentidos que porta el término guerrilla según el Diccionario de la Real Academia Española de la Lengua muestran no sólo su campo polisémico, sino también el legado de las tradiciones y sus tiempos, sea el juego de naipes, la batalla juvenil a pedradas o la partida irregular que practica escaramuzas u hostiga y molesta al enemigo.
} 
resulta ilustrativo el accionar guerrillero del M-26 de Julio en Cuba, ya que en su seno se dibujó el debate y el acuerdo interno sobre los costos y distancias frente a los atentados cometidos por otros grupos de oposición, al mismo tiempo que asumía la ejemplaridad y positividad de los ajusticiamientos selectivos. La otra cara nos remite al régimen dictatorial de Fulgencio Batista y su peculiar estilo de practicar el terrorismo de Estado contra los integrantes o simpatizantes del M-26 de Julio y una más amplia gama de opositores políticos; vela su abierta o latente permanencia que va más allá del dictador Gerardo Machado.

Desde el lado de nuestros protagonistas, podemos comprender que el ajusticiamiento de "orejas", "sapos" y "traidores" ha cumplido una función disuasiva hacia dentro y fuera de la mayoría de las guerrillas latinoamericanas, al mismo tiempo que ha fijado los estrechos límites de la tolerancia armada. Más discutibles han sido los usos guerrilleros de explosivos en blancos ciegos, que borran las fronteras en que se mueven tanto la población civil, como las bases de apoyo de uno y otro bando. Recapitulemos afirmando que la guerrilla es algo más que su táctica terrorista eventual o recurrente, tanto como el Estado contrainsurgente es algo más que el puro terror institucionalizado.

En lo general, la significación de las guerrillas y de los movimientos guerrilleros ha potenciado las más variadas líneas de investigación en las ciencias sociales y algunas disciplinas humanísticas, a la que habría que sumar algunas controversiales ramas especializadas como la psicología militar y/o antisubversiva (Watson, 1982). Sin embargo, pocos saben que la violencia guerrillera ha servido de soporte principal para la constitución de un saber transdisciplinario muy latinoamericano; nos referimos a la denominada "violentología", nacida no por casualidad en los espacios académicos colombianos de los años sesenta (Guzmán y otros, 1962) y expandida más tarde a varias academias nacionales del continente. ¿Cómo olvidar ese texto fundante para los profesores de la UNAM elaborado a mediados de los ochenta por el desaparecido Enrique Valencia sobre la guerrilla latinoamericana, tan deudor de ese saber emergente y polémico de su tierra natal? En los ochenta, la violentología latinoamericana marcaba implícitamente sus distancias frente a la heterodoxa tanatología política, ese saber sobre la agresión y la muerte de inspiración freudiana y marcusiana que se apropia y recrea de la vieja propuesta de Elie Metchinikof (1901), o ante la más convencional "polemología”, o saber militar acerca de las guerras y los conflictos armados, fundada por Gastón Bouthoul y asumida por la ONU desde los primeros años de la posguerra o más propiamente del comienzo de la Guerra Fría. Al cierre de ésta última fase histórica, cobró notoriedad la doctrina Reagan sobre la seguridad hemisférica al popularizar al terrorismo como su más preciada categoría ideológica, la cual, además de haber trascendido los límites coyunturales de su primigenia enunciación, viene operando en la actualidad como el prisma omnicomprensivo de muchos de los estudios sobre 
las guerrillas latinoamericanas. No nos quepa duda de que las entradas teóricas y metodológicas sobre las guerrillas constituyen un capítulo de estos saberes en proceso de construcción y por ende en debate abierto en América Latina. Los historiadores que quieran aproximarse al estudio de las guerrillas en México o en el continente deberían abrir el diálogo con sus pares de otras disciplinas o transdisciplinas, bajo riesgo de esclerotizar precozmente sus lecturas o caer en la levedad empirista o historicista, o peor aún en la simplificada lectura reaganiana, muy de moda tras los sucesos del 11 de septiembre.

Debo advertir, coincidiendo con Villaveces, que "la conceptualización de la violencia borra en sí misma el hecho violento", su lado humano, y estos saberes como la violentología y otros, más allá de lo que pretenden explicar, deben a su vez ser interpelados por la función que cumplen en nuestro tiempo y en nuestra sociedad (Villaveces, 1996: 1). Este hecho viene a cuento, toda vez que la producción de los estudios sobre las guerrillas o acerca de la guerra sucia en México y América Latina moviliza socialmente, en nuestros imaginarios, discursos e imágenes contradictorias sobre la violencia, bajo la lógica del descubrir y velar lo que pretende significar. Estos discursos e imágenes se alimentan o confluyen con los que por vía mediática o institucional ya circulan, volviendo más complejos los campos de significación en que nos hemos movido, moveremos y debatiremos (Guthmann, 1991). Recuperemos, pues, la fuerza heurística de una obviedad, que el contexto desde el cual venimos construyendo nuestras preguntas sobre el pasado o presente guerrillero y las respuestas emergidas de nuestros avances o resultados de investigación también filian su función social, por lo que resulta obvia nuestra ausencia de neutralidad ideológica y de asepsia teórica y documental. Cada quien se ubicará donde deba, pueda y/o quiera estar. Nuestras preocupaciones por lo que contienen o no contienen los archivos oficiales letrados sobre la guerra sucia en México no son gratuitos, tampoco nuestros encantos y desencantos temáticos o teóricos. Si bien la Guerra Fría ha perdido fuerza en el escenario global, en México y América Latina no han desaparecido sus representaciones y prácticas duras, llámense políticas y militares, documentales e investigativas; diríamos que más bien se han actualizado, aggiornado. A partir de los años setenta, la traducción de la doctrina de la seguridad hemisférica en la doctrina de seguridad nacional no escamoteó la elaboración y aplicación de proyectos subregionales de coordinación antiguerrillera y anticomunista como los de la CONDECA para el área centroamericana o del Plan Cóndor para los países de la Cuenca del Plata y del Cono Sur. Del otro lado, permite explicar la necesidad de la construcción de la Coordinadora Guerrillera Simón Bolívar y su estrategia multilateral: en los años ochenta, a veinte años del fallido primer proyecto continentalista guerrillero del Che Guevara. 
Quizá por ello, entre la cómoda visión etic, que pretende traducir el habla de los protagonistas, y la visión emic, que apunta ingenuamente a otorgar voz coral e interpretación nativa a los que muchas veces temen hablar o no quieren, hay muchas mediaciones y posibilidades. La visión emic del quehacer guerrillero, es decir, de nuestros privilegiados protagonistas, ya que no los únicos, dista de guardar homogeneidad y da juego a sus diversas tradiciones culturales e ideológicas. A partir de la segunda mitad de los años setenta, la circulación e intercambio de tradiciones guerrilleras puede y merece ser seguida desde cada experiencia nacional. Este proceso de intercambios y reelaboraciones de experiencias y tradiciones tiene que ver, en parte, con la formación de nuevas organizaciones guerrilleras a las que concurrieron varios cuadros sobrevivientes del primer periodo (1958-1975), pero también gracias a sus políticas de alianzas o frentes armados, así como a la asimilación de algunos exiliados o combatientes internacionalistas. A partir de allí, quizá podemos hablar más propiamente de una cultura guerrillera latinoamericana, al punto que en la actualidad algunos analistas, después de recorrer las webs guerrilleras y sus muchos links, hablan de que ya les llegó la globalización.

El panorama del último medio siglo permite constatar que la recepción continental de las experiencias guerrilleras internacionales no fue pasiva y que su particularidad ha estribado en sus cuotas de heterodoxia y creatividad, emergidas del ámbito cultural y popular en que quedaron inscritas. La visión emic de las guerrillas latinoamericanas se ha movido y se mueve entre sus tradiciones letradas, orales e iconográficas. Esta visión ha generado una frondosa producción de manuales y escritos no siempre convergentes sobre sus modos de categorizar su accionar político y militar, fuera de obviar sus tensiones frente a la oralidad de los saberes prácticos legados a los combatientes de relevo. Transitamos así de La Guerra de Guerrillas del Che, pasando por el Minimanual del guerrillero urbano de Carlos Marighella, a la menos consultada y sumergida tradición oral. Así las cosas, resulta verosímil aquel pasaje que relata el modo en que el Viejo transmite a Lucio Cabañas añejas experiencias armadas bajo los mandos de Amadeo Vidales y Silvestre Mariscal y sus consejos sobre las mañas políticas y militares del gobierno (Montemayor, 1994: 107). Además de ello, la visión emic de la guerrilla se ha afirmado con base en un diálogo experiencial no siempre explícito frente al saber y accionar de sus perseguidores, incluido el manejo de armas aprendido por un número significativo de cuadros guerrilleros que pasaron por el servicio militar obligatorio o la voluntaria formación castrense. De otro lado, la contrainsurgencia busca capitalizar el saber de los guerrilleros que, por vía de la deserción, la infiltración, el chantaje o la tortura, se alinean con el ejército. Sin embargo, el viejo apotegma de conocer al enemigo tanto o mejor que la propia organización opera más como representación que como saber; no lo olvidemos. 
El campo de la recepción del saber guerrillero en América Latina es más viejo de lo que suponemos, independientemente de que la particularidad de su recepción y uso radique en expresarse en sus planos tácticos y estratégicos de manera discontinua. Recordemos uno de sus primeros antecedentes letrados. Cuando comenzó a circular el texto cominternista titulado la Insurrección Armada (1931); elaborado por un colectivo que usó el seudónimo de Neuberg, la sistematización de los caminos de la violencia revolucionaria confería a este manual revolucionario cierto espacio a las fuerzas irregulares (las guerrillas, pues), aunque cargado de exageradas virtudes disciplinarias e ideológicas. Aunque los ecos de esta obra llegaron a través de España a los escenarios latinoamericanos, fueron bastante opacados por el coetáneo y más difundido texto de Arnold Losovsky, De la huelga general a la toma del poder. Recuérdese que este texto de fines de los años veinte orientó uno de los virajes de los ochenta cumplidos por el EPL maoísta colombiano, llegando a pesar más que los escritos militares del propio Mao (Villaraga y Plazas, 1994: 241). De otro lado, debemos mencionar a Julio C. Guerrero, el único latinoamericano invitado a la URSS por el Estado Mayor del Ejército Rojo con motivo de su décimo aniversario en 1928, quien cuatro años más tarde redactó lo que podríamos llamar nuestro primer clásico de este original saber práctico y particular acerca de la violencia intitulado La guerra de guerrillas, una modalidad de lucha del futuro (1932), aunque entre los especialistas andinos haya sido más conocida su segunda edición boliviana de 1940. Guerrero implícitamente tomó distancia frente a los textos de Neuberg y de Losovsky, obras que conocía de primera mano, apreciando mejor las experiencias nacionales e internacionales desde el tiempo largo. Guerrero, antes de fallecer, participó en dos cerrados grupos de discusión sobre los límites de las experiencias guerrilleras peruanas de los sesenta, entre cuyos integrantes se encontraban algunos cuadros de las dos principales guerrillas de los años ochenta4. Tampoco podemos olvidar al experimentado militar republicano español Alberto Bayo Giraud (1892-1967), quien aportó a los expedicionarios del M-26 de Julio sus conocimientos en guerra irregular, sistematizándolos en sus 150 preguntas a un guerrillero (1959). Por todo ello, la historia particular de cada guerrilla o movimiento guerrillero, que no es lo mismo, no debe sobrestimar su expresión coyuntural regional, nacional o internacional sin aproximarse a sus otros espejos del siglo XX y sin desestimar el debate mayor que los involucra en los no consensuados campos teóricos y metodológicos de los saberes anteriormente aludidos. Los espejos cruzados de la Revolución Rusa, de la Guerra Civil en España, de la lucha de liberación nacional en Argelia y Vietnam, de la Revolución China, de la Revolución Mexicana y de la Revolución Cubana, han

${ }_{4}^{4}$ Comunicación personal de N1, militante del PCP, Lima, 27 de abril de 1972; Comunicación personal de N2, militante del MIR, Lima, 8 de enero de 1979. Todas las entrevistas serán marcadas por un numeral que acompañará a la letra $\mathrm{N}$, omitiendo así los referentes de identidad. 
gravitado de diversas maneras en los imaginarios y las lógicas de la recepción guerrillera latinoamericana. Las redes internacionalistas, además, abrieron juego tanto a los relatos sobre los martirologios como a los saberes guerrilleros en desarrollo.

\subsection{La violencia, la nueva izquierda y la Guerra Fría}

Tratemos ahora de situar la problemática histórica de nuestras guerrillas bajo los signos de un tiempo compartido y sus múltiples escenarios supranacionales. Hannah Arendt en su conocido ensayo Sobre la violencia (1969) se extrañaba que ésta, la violencia, no obstante su ostensible gravitación en la historia del siglo XX como lo predijo Lenin, fuera tan poco atendida y estudiada por los intelectuales al punto que ni siquiera fuese objeto de conceptuación en el Diccionario Internacional de las Ciencias Sociales; tardarían un decenio en llegar otros aires y las primeras conceptuaciones. Pesaba más el estereotipo de la violencia guerrillera, al suponer que toda acción política violenta o revolucionaria contra el gobierno y/o el Estado era sinónimo de acción guerrillera o terrorismo y que toda acción guerrillera o terrorista era producto de una infiltración y conspiración extranjera o del otrora denominado internacionalismo proletario. Esta visión simplista, que fue popularizada por los medios a partir de los sesenta, puede ser filiada como un subproducto ideológico de la Guerra Fría Este/Oeste, Occidente/Oriente. La guerrilla sería, así, convertida en metáfora oriental y símbolo comunista, siendo su más temible referente la Cuba socialista.

En el curso de los sesenta, decía Arendt y no sin razón como lo refrenda el cuadro latinoamericano, la nueva izquierda venía glorificando la violencia apoyándose en autores como Fanon, Sartre y Mao y aun en el viejo Sorel, distanciándose de las tradiciones políticas de sus antecesores y opositores marxistas, reformistas o pacifistas (Sorel, 1935; Marcuse, 1968)5. La cultura política de los guerrilleros y revolucionarios de todo el mundo quedó así marcada por este acontecimiento ideológico, que operó como un parteaguas en la historia de la izquierda mundial. El elogio de la violencia, como remedio frente al reformismo obrerista de la vieja izquierda proclamado por Daniel Cohn Bendit, atenuó los efectos del estigma leninista sobre "el izquierdismo, enfermedad infantil del comunismo", aunque no siempre, si rememoramos el caso de los "enfermos", la controvertida guerrilla mexicana de Sinaloa a inicios de los setenta.

El escenario latinoamericano obligaría a matizar tal juicio por tres circunstancias y movimientos que van en sentido divergente en la nueva izquierda latinoamericana a partir de la Revolución Cubana y la traducción del Mayo del 68

${ }_{5}$ En cuanto a las reediciones militantes de los escritos de Mao en América Latina, distan de haber sido inventariadas. 
francés o la Revolución Cultural China, en el 68 mexicano, el 69 argentino (Sarlo, 1998) y los poderes insulares del maoísmo en las universidades ecuatorianas y peruanas. La primera, que a pesar de la censura política mayor o menor según los países, el decenio del sesenta comenzó a ensanchar la cultura letrada y militante gracias a una oferta editorial expansiva de viejos y nuevos textos de la izquierda occidental, oriental y latinoamericana, la cual fue acompañada, no sin tensiones, por los productos ideológicos de las maquinarias radiofónicas y propagandísticas de los escindidos socialismos realmente existentes. La segunda reconoce que, si bien un sector significativo de la nueva izquierda latinoamericana se adhirió a la vía armada en sus diversas variantes, no se puede desdeñar sin más a la vieja izquierda, ya que algunos partidos comunistas, como el colombiano o el guatemalteco, encontraron puentes entre sus viejas tradiciones y su novísimo accionar guerrillero, a las que habría que sumar las escisiones proguerrilleras cumplidas en otros países de la región. No es novedad decir que la gravitación de la Revolución Cubana fue decisiva, aunque también contaron las experiencias revolucionarias en China, Corea y Vietnam, más que la retórica soviética sobre la coexistencia pacífica Este/Oeste, a las que hay que sumar los ciclos de entrenamiento internacionalista. Bajo esa agitada atmósfera ideológica y cultural de la segunda mitad de los años sesenta, el Che Guevara no tardó en convertirse en el icono emblemático de la nueva izquierda latinoamericana, es decir, en la imagen salvacionista del guerrero de los pobres y oprimidos, figura no muy distante de las que para otro tiempo y escenario Le Goff encuentra en las representaciones sobre el proletariado, el partido, el gran líder, como recreaciones socialistas o comunistas de una tradición utópica de larga duración. La tercera vertiente es menos visible y revela una nueva izquierda latinoamericana filogramsciana que no fue seducida por la vía guerrillera, prefiriendo optar por el proyecto de minar la cultura autoritaria de la que formaba parte, a favor de construir una inédita polifonía de tradiciones olvidadas, reprimidas y emergentes, orientada a configurar un inédito movimiento intelectual y político a favor de la democracia socialista (Aricó, 1999).

Arendt pretendía en su ensayo salir al paso a la nueva izquierda por otro camino, el de dislocar la categoría de la violencia y sus relatos y prácticas de la más genuina y occidental tradición marxista, además de reabrir como nueva la discusión sobre medios y fines, obviando la discusión sobre la violencia institucionalizada del poder. Mucho antes que ella, Walter Benjamin, en su ensayo Para la crítica de la violencia, nos daba otra versión. Para Benjamin, la conceptuación y crítica de la violencia no podía ser disociada del debate sobre la justicia y el derecho ni de los eslabonamientos existentes entre los diversos géneros de la violencia real o representada. Nuestro ensayista constataba las contradicciones del derecho positivo de querer encasillar los géneros de la violencia en el campo de los medios legítimos e ilegítimos, independientemente de sus fines como ingenuamente antes había 
sostenido el derecho iusnaturalista. Benjamin destacaba el hecho de que tal planteamiento suponía una premisa no discutida, un poder que ejercía el monopolio jurídico de la violencia y por ende de los aparatos de sanción y represión, incluida la discrecional muerte del trasgresor del orden legitimado. Consideraba que frente a este poder se oponía una violencia que potencialmente era creadora de derecho, es decir, que gracias a la alteración del orden se abrían las compuertas a la posibilidad de configurar uno distinto. Los casos de Cuba y Nicaragua dicen mucho de los orígenes de un nuevo derecho, más allá de sus aspectos controversiales. Benjamin veía con perspicacia el eslabonamiento entre el derecho de huelga con otros géneros más duros de la violencia política revolucionaria y, aunque no refería el caso particular de la práctica guerrillera, la abstracción de su planteamiento bien podría incluirla (Benjamin, 2001: 109-112).

Por su lado, la Arendt, recuperando una apreciación del viejo Engels, recordaba que un rasgo constitutivo y diferencial de la violencia radicaba en que ésta "siempre requiere implementos" y que éstos, a su vez, quedan subordinados a la historia de sus cambios tecnológicos (Arendt, 1970: 9). Aquí nuestra aguda y controvertida ensayista subrayaba que la producción de implementos de la violencia estaba ubicada en el campo bélico, monopolizado tendencial e históricamente por las grandes potencias. Ella consideraba que el tiempo de la nueva izquierda estaba anudado con "el extraño desarrollo suicida de las armas modernas; esta es la primera generación crecida bajo la sombra de la bomba atómica” (Arendt, 1970: 18). Agregaríamos que el viejo referente simbólico de la violencia como hecho de sangre, es decir, de su derramamiento justificado o prohibido, se contrajo gracias al poder aniquilador no sólo de la bomba atómica, sino también de las bombas de napalm, fósforo y otras sustancias letales. Sangre y violencia no serán ya sinónimos en el arte de la guerra y de la violencia contemporánea. Este no es un hecho menor, ya que este técnico desvanecimiento, ocultamiento o desaparición cromática, visual y textual de la sangre derramada, entendida como el sentido simbólico que anuda a los géneros de la violencia, niega su carga mítica, sagrada y valorativa (Chevalier y Gheerbrandt, 1999: 909-910). Los despliegues mediáticos de las guerras del Golfo y Afganistán han logrado una asepsia de la imagen aceptable e interesada frente a los hechos de sangre de la violencia social o política; quizá asistimos a la producción occidental de una nueva simbólica y retórica acerca de la aniquilación del otro. Hasta aquí hemos seguido el razonamiento de la autora, pero no las conclusiones a las que arriba, selladas por el confeso occidentalismo de su teoría política y su arbitraria hermenéutica de la obra de Marx, Engels y Lenin, ni su sobreestimación de la concentración y control de implementos técnicos de la violencia en manos del Estado contemporáneo.

Recordemos que el común denominador de las estrategias guerrilleras latinoamericanas de cara a su propio armamento suscribía la apuesta de proveerse 
del mismo por diversos medios de los propios aparatos de fuerza de los Estados a los que confrontaba o enfrenta, además de su adquisición en el mercado subterráneo de armas, antes que depender de la ayuda cubana como interesadamente la reinventa y sobredimensiona Jorge Castañeda en su Utopía Desarmada (1993). El uso de armamento pesado convencional forma parte más bien del proceso de desarrollo y conversión de la guerra de guerrillas en guerra de movimientos y principalmente de posiciones. Las guerrillas latinoamericanas, vistas en su conjunto y en el ciclo de cuatro decenios, han transitado gradualmente del uso de revólveres, carabinas y fusiles máuser al uso de las escuadras de 9 milímetros y los "cuernos de chivo", y del uso de los cartuchos de dinamita y las molotov al empleo de las granadas y bombas de plástico, dinamita pura o del anfo bajo dispositivos de explosión retardada.

Una revisión de los testimonios y memorias de los guerrilleros latinoamericanos indica que han tenido fundadas razones para dedicar pasajes especiales a sus modos de eludir o atacar a helicópteros y aviones adaptados a la guerra contrainsurgente. La acción guerrillera tiene sus lógicas diferenciales de valorar los medios técnicos de la acción armada; variando de organización a organización, de corriente a corriente, sus extremos se ubican entre el voluntarismo que va en busca de las armas y el determinismo técnico de su acumulación ${ }^{6}$. Cuentan igualmente los intercambios de experiencias o las acciones conjuntas, que suscitan reelaboraciones y préstamos culturales y técnicos altamente apreciados. Un cuadro del EPL dice sobre una experiencia inédita en América Latina, vinculada al Batallón América de la Coordinadora Guerrillera Simón Bolívar:

Fue una experiencia valiosa en términos de intercambio de vivencias. Por ejemplo, podemos decir que el M-19 nos dio grandes enseñanzas en el campo militar, nos enseñó a pelear mejor, a ser mejores guerreros. Ellos tenían una concepción de la lucha menos guerrillerista, le decían no a aquella táctica de la pulga que muerde y escapa. Se trataba de plantársele al enemigo en el terreno, de desafiarlo, de hacer operaciones grandes; poner al servicio de la guerra la técnica, por ejemplo, en las comunicaciones, en explosivos y en otras cosas que a ellos se les ocurría. Si era necesario sacar a un compañero en helicóptero, ellos se conseguían el aparato y sacaban al compañero de la zona” (Villarraga y Plazas, 1994: 198-199).

\footnotetext{
${ }_{6} \mathrm{~N} 5$, un cuadro regional del ERP argentino en el exilio sobrestimaba el peso del novísimo arsenal militar que habían adquirido, -real o inventado- consideraba que gracias a él su organización podría remontar los reveses sufridos en la última fase de su accionar guerrillero, la realidad fue más dura que su determinismo técnico. El espejo paradigmático seguía siendo Vietnam. Comunicación personal, México, 14 de abril de 1977.
} 
Pero volvamos al escenario mundial que dibuja la Arendt para entender la atmósfera que condicionó la glorificación de la violencia desde la nueva izquierda; aunque desde otro mirador, Wolf-Dieter von Ebenweing en su ambicioso balance de los conflictos armados sobre el siglo XX ha sostenido que, durante los años de 1966 a 1976, se triplicó la cantidad de conflictos armados en el escenario mundial y se dobló el número de países involucrados, que los acaecidos en los seis decenios precedentes. Los escenarios continentales más violentos fueron Asia y Medio Oriente, mientras que América Latina fue pintada como la segunda región más pacífica del mundo después de Oceanía, ni más ni menos cuando florecían sin fusionarse nuestras emergentes izquierdas de nuevo tipo y nuestras ahora recordadas guerrillas. El lenguaje de las armas de nuestras guerrillas primigenias, salvo el cubano, no pesó en esta cartografía internacional del conflicto armado. El mirador geopolítico mundial nos permite redimensionar el peso real de nuestro accionar guerrillero frente al desplegado por los vietcong, por ejemplo, olvidándonos de los nada piadosos khmer rojos en sus respectivos tiempos y escenarios.

Creemos que una cartografía y cronología guerrillera a partir de la posguerra complementaría la recortada visión de von Ebenweig, pero no alteraría sustantivamente su visión del cuadro mundial del conflicto o de la violencia armada. De otro lado, esta visión nos recordaría que, a pesar de los limitados alcances de las guerrillas latinoamericanas, éstas fueron objeto de puntual seguimiento y control hemisférico por parte de los ejércitos y países adheridos al Tratado Interamericano de Asistencia Recíproca (TIAR) liderado por Estados Unidos bajo la lógica de la Guerra Fría. La reciente apertura de fuentes otrora consideradas confidenciales en Estados Unidos, México y otros países de la región, permiten repensar la guerrilla local por su contradictoria articulación con las coordenadas de la seguridad hemisférica. El asedio mexicano a la avanzada de la guerrilla guatemalteca liderada por Yon Sosa hasta su aniquilamiento revela claves interamericanas, así como la muerte de Rubén Jaramillo en 1962 (Hernández, 2001), para no referir el más conocido caso del Che Guevara (Ratner y Smith, 1997: 256-295).

Reiteramos que las guerrillas latinoamericanas no sólo se enfrentaron a los poderes locales, regionales y nacionales; también resintieron los embates y las estrategias contrainsurgentes del TIAR. La Guerra Fría se tradujo en asesorías político-militares interamericanas, cursos de entrenamiento bajo el Comando Sur de Estados Unidos, venta o donación de implementos técnicos propios para la guerra contrainsurgente, que las guerrillas latinoamericanas para sobrevivir debieron ponderar con desigual fortuna.

Historiar las guerrillas requiere compenetrarse con algo más que nuestras historias nacionales, pero sorteando las trampas del deductivismo y la otra cara de la historia conspirativa haciendo más diestra y eficaz de lo que realmente es a la 
mano imperial. El Movimiento 26 de Julio, a fines de los años cincuenta, y el Frente Sandinista de Liberación Nacional, a fines de los setenta, nos dan luces al respecto.

La mayoría de las guerrillas rurales en los países andinos y mesoamericanos ha dejado entrever las dificultades de su acción en contextos interétnicos, así como la dificultad aún mayor de ensanchar en ellos sus bases de apoyo. Un comandante del Ejército Guerrillero de los Pobres recuerda que en la región del Ixcán, él y sus compañeros escucharon: "por vez primera la palabra macá, vocablo terrible que para nosotros significaba entonces algo más que el simple no hay, adoptando toda una connotación de rechazo con raíces de siglos" (Payeras, 1981: 35). No fue diferente la incapacidad de las guerrillas colombianas para arraigarse en la sierra de Santa Marta. Otra suerte no menos dramática por su aislamiento han corrido las guerrillas de explícita filiación indígena como las del Quintín Lame en la región del Cauca en Colombia, la guerrilla katarista en el altiplano boliviano o la de la ORPA en la región del Ixcán en Guatemala, antecesoras de las del ERPI mexicano. El caso de la guerrilla indígena en la Costa Atlántica de Nicaragua no puede ser reducido tan fácilmente a la lógica de los contras antisandinistas y la infiltración de la CIA. El cuadro se dibuja mejor al considerar a los frentes guerrilleros de base étnica de organizaciones como Sendero Luminoso entre los ashaninkas en la Amazonia o en la región chanka de los Andes peruanos. Frente a ellas, el costo depredador de la guerra contrainsurgente en las zonas indígenas ha tenido un curso genocida $y$ etnocida, a lo que se agrega una cuota de exclusión étnica, sea en los acuerdos de paz o en el fracaso de su aplicación como lo evidencian los casos de Nicaragua y Guatemala. Más recientemente, las fracasadas negociaciones de paz en Colombia ya habían dejado fuera al gobierno autónomo de la región indígena del Cauca, que sigue resintiendo la presión de dos fuegos y acaso el indeseado fantasma de los acuerdos guatemaltecos.

A manera de breve balance del sinuoso periplo guerrillero, podemos afirmar que sus particulares búsquedas de legitimidad intentaron apoyarse en los signos ideológicos propios de la corriente hegemónica de la nueva izquierda, en la lectura de su problemática nacional e internacional, así como en la reapropiación de tradiciones de resistencia popular, fuera de su no siempre convergente accionar político y militar. Desde América Latina, podríamos particularizar diciendo que nuestro paso por el siglo XX fue marcado por revoluciones como la mexicana, la boliviana, la cubana y la nicaragüense, guerras entre Colombia y Panamá, Bolivia y Paraguay, Perú y Ecuador, Honduras y El Salvador, múltiples resistencias armadas contra las ocupaciones militares norteamericanas en el Caribe y América Central, las prácticas terroristas y guerras sucias libradas por nuestros Estados autoritarios y las guerrillas rurales y/o urbanas. Las guerrillas tuvieron su ciclo más importante y generalizado en América Latina en los marcos de la Guerra Fría, particularmente entre los años sesenta y ochenta del siglo pasado. No hay país que no haya 
registrado experiencias guerrilleras de izquierda en el curso de esos tres decenios; en cambio, las filiadas como de derecha están por ser estudiadas. Otras guerrillas, muchas, en clave liberal o conservadora, nos remiten al siglo XIX.

La historia y cartografía guerrillera en el continente está por hacerse y de la nuestra, la mexicana, no se diga. Pero hemos de advertir que no hay nada más paradójico que someter a la guerrilla latinoamericana a un proceso ordenador, el cual marca nuestro quehacer académico. Leer la guerrilla es conferirle orden, identificar protagonistas, adscribirle acotados sentidos de representación y acción, marcar sus tiempos y lugares. No se dude que la guerrilla, como metáfora del caos social y político, nos hará ruido de muchos modos; dista de ser un objeto pasivo y desligado de la problemática contemporaneidad que nos toca vivir. México vive un nuevo ciclo guerrillero, discreto y fragmentado pero real, cuyas señas cobran más visibilidad en el istmo y el altiplano central. Sobra decir que el escenario chiapaneco en que se mueve el EZLN reviste un perfil más complejo de definir, pero que no renuncia a sus sentidos de proximidad con el universo guerrillero mexicano y latinoamericano.

Diremos, por último y a manera de cierre, que el carnaval afecta el propio saber sobre la guerrilla latinoamericana en el que nos hemos involucrado, por acartonadamente serio, por quemante de muerte y violencia elusivas o descarnadas, por juicios fáciles y conceptos evanescentes. Por todo ello, olvidémonos carnavalescamente de las conclusiones para abrir juego al postergado diálogo sobre lo políticamente nombrable y lo culturalmente sumergido o viceversa.

\section{Muerte, martirologio y mitología del renacer en las guerrillas latinoamericanas}

\subsection{Simbolización y ceremonialización de la muerte}

La violencia política en su desarrollo, y aquí mirada desde el ámbito guerrillero, despliega su propia simbólica dentro de sus procesos rituales (iniciación, combate, muerte) y, a veces, ésta los trasciende. La construcción cultural de las virtudes violentistas en las guerrillas latinoamericanas, exaltan un patrón de simbolización fuertemente masculinizado, que juega con la equivalencia entre lo viril y lo heroico, combatir como ofrendar o perder la vida es cosa de machos, independientemente de que hayan o no guerrilleras ejemplares o heroicas. Los referentes femeninos tienen que ver con el reposo del guerrero, la muerte incluida, y quizás y en su contradictoriedad, con la mitología del renacer que veremos más adelante. Una conocida canción nos recuerda dos de sus sentidos fuertes con aquello de "a parir madres latinas, a parir más guerrilleros". En el imaginario guerrillero, la muerte heroica entendida como objeto de deseo, parece tener esta olvidada y densa 
carga simbólica. Sin embargo, nuestra entrada a la simbolización y ceremonialización de la muerte nos orienta a retomar de otro modo un peldaño previo, es decir, uno de los rostros más duros de la violencia. Es así que consideramos que en América Latina, una cadena semántica inclusiva vincula la violencia, la crueldad y la muerte bajo los órdenes etnoclasistas excluyentes y opresores de cada país. Pero esta lógica no es patrimonio exclusivo de nuestros escenarios nacionales como nos lo ha recordado Barrington Moore cuando escribe que

La crueldad hacia los estratos bajos encuentra su justificación en la idea de que, en cierto sentido, no son verdaderos seres humanos. Principios similares se dan en el combate. Ahí donde el enemigo se define como inhumano o inferior, las crueldades más severas pueden aparecer como justificadas moralmente, y no producen irritación (Moore, 1989: 41).

En la medida en que las guerrillas se involucran con los estratos populares y marginales de la sociedad, experimentan en mayor grado las caras de la crueldad de los de arriba y sus aparatos de fuerza hacia los de abajo, las cuales potencian, a su vez, sus replicantes extravíos y excesos7. El ejercicio de la crueldad parece revelarnos la más oscura frontera de la violencia patriarcal al paso de los tiempos, aunque dista de explicar sus variadas y conmovedoras expresiones. Otras veces, la violencia simbólica asume contornos salvacionistas desde el inframundo, la noche y el reelaborado tiempo mítico del retorno, a veces con Votán Zapata, en 1994, que viene del mundo de los muertos acompañando a los mayas alzados en armas, o más atrás, en 1966, con Incarrí entre los pobladores de una localidad andina en Perú, quien apareció redivivo a través de un aislado sobreviviente de la ya derrotada guerrilla del ELN a quien consideraron uno de sus mensajeros. Los comuneros quechuas protegieron al guerrillero y lo acompañaron en una mesiánica acción de resistencia local hasta el aniquilamiento de su poblado y su gente mediante inclemente bombardeo aéreo8. También potenciaron un mito sobre la invulnerabilidad del guerrillero como sucedió con Horacio Juárez por las mismas fechas en una zona andina cercana al accionar guerrillero de $1965^{9}$.

Hugo Blanco, un dirigente campesino cuzqueño convertido en episódico guerrillero a fines de los años cincuenta y todavía bajo la posibilidad de que le

\footnotetext{
7 N4, un excomandante del EPL y más tarde del M-19, argumentaba con la pasión de su propia experiencia armada regional, que el límite del terrorismo de Estado estaba determinado por la fuerza disuasiva del incrementado terror replicante y ejemplar de la guerrilla, obviaba acaso la diferencia entre los escenarios de mayor envergadura y sus lógicas de fuerza. Comunicación personal, México, 6 de octubre de 1982.

8 Versión escuchada entre los estudiantes migrantes de la Universidad Nacional de Huánuco en Perú, adheridos al Frente Estudiantil Revolucionario (FER), verano de 1967.

${ }_{9}$ Comunicación personal del antropólogo Juan José García Miranda, 9 de agosto de 2002.
} 
aplicaran la condena a muerte, escribió en la prisión un texto alusivo a nuestro tema y en él ratificó la adhesión a la vida como una obligación revolucionaria que es premisa para hablar de la muerte misma. Se trata de un acto inevitable de reelaboración ideológica y cultural que considera a la muerte violenta como un riesgo propio de este modo de "vivir peligrosamente" que hay que asumir, dice Blanco:

Ser revolucionario es amar al mundo, amar la vida, ser feliz, por eso no huye de la vida, sabe que es su obligación vivir para luchar y le gusta vivir.

¡Pero tampoco huye de la muerte!

Porque también muriendo se combate; porque también muriendo se transforma al mundo. ¡Porque también muriendo se ama la vida! Porque también muriendo se vive. Por eso también le gusta morir.

Y para el revolucionario peruano no es desgracia morir. No puede ser desgracia que mi sangre vaya a ese río combatiente y rojo por donde está corriendo y luchando la sangre de Lucho Zapata, de De la Puente, de Lobatón, de Heraud, de Vallejos, de Velando.

No es desgracia dar un abrazo ¡Tierra o Muerte! a Remigio Huamán en la sangre Padre, la de Túpac Amaru el eterno (Blanco, 1972:104).

Esta representación simbólica de la muerte que ofrece Hugo Blanco no se agota en la retórica marxista faccional de separar el martirologio guerrillero más allá de sus filiaciones orgánicas o espontáneas, del más amplio inserto en la cultura política de la izquierda peruana o latinoamericana. La visión de Blanco revela también una clave etnocultural alusiva a Túpac Amaru, ese personaje que años más tarde daría nombre a la más famosa guerrilla urbana de América Latina en la lejana Montevideo de los años setenta, así como a la última guerrilla peruana de los ochenta. La representación guerrillera de Túpac Amaru que configura Hugo Blanco tiene una carga mítica fuerte y expansiva en Perú, la cual une la vida y la muerte en el ciclo del renacer del héroe cultural andino, borrando por un lado la frontera entre los relatos orales y escriturales y, por el otro, la distancia entre los referentes de la cosmovisión inca y la cristiana. No es accidental que en 1958, justo cuando Hugo Blanco se dedicaba a la tarea de la agitación y organización del campesinado quechua en el Cuzco, el poeta Alejandro Romualdo, uno de los primeros en adherirse a la corriente guevarista peruana, desde otro escenario regional escribiera su Canto Coral a Túpac Amaru que es la libertad; leamos la primera estrofa y un fragmento de la última:

Lo harán volar / con dinamita. En masa, / lo cargarán, lo arrastrarán. A golpes / le llenarán de pólvora la boca./ Lo volarán: / ¡Y no podrán 
matarlo! (...) Querrán volarlo y no podrán volarlo. / Querrán romperlo y no podrán romperlo / Querrán matarlo y no podrán matarlo / Al tercer día de los sufrimientos, / cuando se crea todo consumado, / gritando ¡libertad! Sobre la tierra, / ha de volver, / ¡Y no podrán matarlo! (Romualdo, 1974: 329-330).

La dialéctica de la violencia guerrillera y la violencia contrainsurgente, simbólica o no, no son ajenas a los otros géneros de la violencia realmente existente. En el curso de los años ochenta, las canciones de combate de los kaibiles guatemaltecos como expresión de la violencia simbólica abren el cauce para su acción depredadora de vida contra los guerrilleros de las fuerzas de la URNG y sus bases y redes de apoyo en la región mayanse: “¡Kaibil!, ¡Kaibil!, ¡Kaibil!, ¡mata, mata, mata!, ¡qué mata kaibil! ¡Guerrillero subversivo! ¡Qué come kaibil! ¡Guerrillero subversivo!" (Sandoval, 1999: 4). Función análoga por los mismos años asume la canción de combate de los "sinchis" peruanos durante su prolongado asedio a las poblaciones que servían de base social a Sendero Luminoso en Ayacucho: "Terroristas de mierda, entraremos esta noche a sus casitas, comeremos sus tripitas, beberemos su sangrecita, cortaremos sus cabecitas, picaremos sus ojitos, aplastaremos sus tobillos" (Montiel, 1985:78).

De otro lado, la construcción cultural del gorila militar en el imaginario de la izquierda latinoamericana de los años sesenta se ha ubicado en la misma dimensión de la confrontación simbólica que venimos comentando (Piretz, 1988: 959-960). Así las cosas, los guerrilleros, militares y paramilitares quedan inmersos como actores en una espiral de violencia simbólica y real de difícil pronóstico que tiene a la muerte como centro, alcanzando de diversas formas a los demás actores sociales. A la construcción y usos de las mitologías sobre la naturalización y bestialización del enemigo y que legitiman su muerte, habría que sumar la aguda advertencia de Benjamin acerca de la importancia de estudiar los orígenes, la lógica y los usos del dogma sobre la sacralización de la vida que considera de reciente, interesado y fallido intento occidental a favor de su resacralización (Benjamin, 2001:128).

Considerar la cultura guerrillera presenta diversos problemas de una representación compartida emic-etic; el principal es cierto reduccionismo clasista y doctrinario de la cultura popular y guerrillera (Chartier, 1999: 13-44). Lo ilustran las FARC, en una paradojal justificación que intenta abarcar sus prácticas culturales revolucionarias y su retórica acerca de su "cultura de la paz con justicia social". De la primera, destaca la obra narrativa titulada La luna del forense que le otorga una insoslayable presencia simbólica y positiva de la muerte entre los vivos (Resistencia, No. 29, marzo-junio de 2002:1). La muerte no es ajena a las expresiones de la cultura guerrillera de las FARC, como no lo es tampoco a los modos en que se expresa la cultura popular que filia a su vez algunas particularidades de sus 
respectivos frentes. En general, la muerte gravita también en la más estricta tradición letrada guerrillera, la cual a su vez queda inserta en su campo cultural.

En otro tiempo, el "vivir peligrosamente" signó en palabras de José Carlos Mariátegui a los revolucionarios del mundo en ese ciclo insurreccional que transitaba de la Revolución Rusa al nuevo curso guerrillero de la Revolución China que se iniciaba en 1927 y que tuvo expresiones próximas en México y Brasil. Tres decenios más tarde, el "vivir peligrosamente" de los guerrilleros latinoamericanos los ponía de cara a la muerte en su quehacer cotidiano, por lo que los involucraba en una reelaboración simbólica de la misma, mediada muchas veces por la construcción de rituales de protección de sus vidas, del aprendizaje de los modos de aniquilamiento de los presuntamente traidores y enemigos, de la construcción de una política de la memoria frente a los caídos y sus héroes culturales. El propio Hugo Blanco el 24 de noviembre de 1966, de cara al impacto de las ya disminuidas acciones guerrilleras del MIR y del ELN, producto de sus bajas, debilidades y errores y que preludiaban su derrota en Perú, reitera la gravitación de la muerte en términos elocuentes: "No es desgracia la muerte militante. Para el revolucionario eso es morir de muerte natural."

Desde otro tiempo y contexto diferente, esa imagen de la muerte reaparece en las representaciones de un guerrillero sandinista aunque explayándose sobre otros sentidos:

...aquí se puede morir un montón de gente, pero hay que seguir luchando para derrocar al enemigo; porque definitivamente, ser guerrillero, es estar contra la Guardia, aunque murás, ser guerrillero es una actitud moral de vergüenza. Tu muerte es una protesta en sí (Cabezas, 1982: 165).

Las organizaciones guerrilleras tuvieron que enfrentar de diversas maneras el riesgo de muerte entre sus miembros, asunto que reviste muchas aristas según las circunstancias y tradiciones. El ir al frente de la columna, por ejemplo, revela la exigencia de una elaboración ideológica y de una política frente al riesgo, como lo señala un perspicaz registro del EGP:

Alguna vez lloró amargamente, durante cierta reunión de crítica y autocrítica, confesando que siempre le había provocado aprehensión marchar en los primeros puestos de la vanguardia. Aquel sentimiento fue motivado para que esa vez hiciéramos algunas reflexiones en colectivo acerca del llamado destino. Éramos materialistas y, como tales, sabíamos que la muerte era una forma dialéctica del azar, y nadie puede presentirla aunque sí preverla científicamente dentro del cálculo de probabilidades en la guerra (Payeras, 1981: 71-72). 
La relevancia del tema del riesgo de muerte algunas veces devino en un capítulo clave de la formación de cuadros guerrilleros; así lo hacía el EPL colombiano a mediados de los setenta. A las lecturas y charlas sobre la muerte al servicio del pueblo y de la revolución, seguía en la ciudad un encierro de tres días en cuarto oscuro marcado con símbolos mortuorios, caja incluida, donde se inducía al aspirante a guerrillero a asumir la muerte como riesgo natural $\mathrm{y}$ hasta ideológicamente deseable en combate. En el frente rural, el aprendizaje de la muerte se iniciaba con la muerte de un mono, cuyo cadáver había que cargarlo hasta el campamento para proveer de alimento a los compañeros. El acto de matar al mono simulaba dramáticamente la experiencia de matar un semejante, un enemigo. Una y otra experiencia, al decir de uno de los comandantes del EPL, coadyuvaban en la modelación de los nuevos combatientes ${ }^{10}$.

En el interior del universo guerrillero, cobra visibilidad la ceremonialización de la muerte, uno de cuyos capítulos centrales tiene que ver con la construcción de su martirologio en un complejo proceso de repolitización, resemantización y apropiación de sentidos y valores propios de la religiosidad y la cultura popular. La muerte como campo simbólico se expresa como posibilidad y realidad a través de los campos de adscripción individual y colectiva de la guerrilla y sus integrantes como con el de sus adversarios políticos y militares y sus instituciones. Si bien es cierto que la construcción cultural de la muerte en las guerrillas tiene rostros particulares marcados por las tradiciones, los escenarios y las coyunturas, su tematización y problematización en esta breve comunicación nos obligará a desligarnos parcialmente de ellos.

Veamos ahora un caso ejemplar sobre la representación guerrillera de la muerte en una tradición letrada por muchos conocida. En La Guerra de Guerrillas (1962) y en el Diario (1967) del Che Guevara, el tema de la muerte aparece bajo distintos signos y entradas. Empecemos por el segundo y más popular. En el Diario, el tema de la muerte como riesgo cotidiano y real de la condición de guerrillero expresa la lógica diferencial desde la que éste debe apreciar ideológica, táctica y personalmente, las sucesivas pérdidas de sus compañeros de armas. Hay muertes más sentidas que otras y que no necesariamente se corresponden con las que afectan en mayor grado la capacidad de la unidad guerrillera. La muerte disemina sus sentidos en los referentes de pérdida, desgaste, hambre, enfermedad, más que en los más explícitos de las acciones de armas. En el Diario, la muerte ronda las propias notas sobre la supervivencia y el renacer de la propia guerrilla.

El otro libro en realidad es un manual operativo que exhibe una particularidad adicional. Guevara, desde el inicio de la obra, le confiere un sesgo novedoso a la construcción del martirologio guerrillero a través del personaje

10 Comunicación personal de N3, excomandante del EPL, México, 24 de junio de 2002. 
simbólico de Camilo Cienfuegos, convertido en capital letrado dedicado a la guerrilla revolucionaria. Se trata de cómo la palabra escrita potencia la praxis y la simbólica guerrillera guevarista y cómo la heroicidad, gracias a un juego de equivalencias ideológicas y simbólicas, deviene en revolucionaria y popular. En este libro, se pretende sintetizar la experiencia armada cubana para que sirva de espejo a los afines de otras latitudes; allí se habla del combate y sus modos, también del castigo ejemplar al trasgresor, es decir, de la función disuasiva del recorte de la soñada y escasa ración de comida a la muerte misma. Queda explícita la motivación del Che que anima la escritura y la dedicatoria del libro cuando afirma que se basa en el recuerdo y homenaje que dedica al desaparecido líder Camilo Cienfuegos. La muerte como capital simbólico había quedado en entredicho político tras el accidente aéreo que le costó la vida a Camilo Cienfuegos, por lo que Guevara siente la necesidad de tomar posición frente a la acusación de un presunto "ajuste de cuentas". Camilo, al decir del Che, está retratado en el espíritu del manual, porque: "él le dio a la armazón de las letras aquí expuesta la vitalidad esencial de su temperamento, de su inteligencia y de su audacia, que sólo se logran en tan exacta medida en ciertos personajes de la Historia” (Guevara, 1985: 26). Para Guevara es más político y más homenaje a Camilo, la redacción y difusión de un manual operativo que un anecdotario guerrillero. La condición del héroe en Camilo, en la visión del Che, sugiere el camino a seguir mediante el legado que auspicia el manual, por lo que reclama que

no hay que ver a Camilo como un héroe aislado realizando hazañas maravillosas al solo impulso de su genio, sino como una parte misma del pueblo que lo formó, como forma sus héroes, sus mártires o sus conductores en la selección inmensa de la lucha, con la rigidez de las condiciones bajo las cuales se efectuó (Guevara, 1985: 27).

Pero Guevara debe decir lo suyo sobre la muerte particular de Camilo en la perspectiva de repolitizar el infausto accidente y delinear su ingreso al panteón en construcción de los héroes guerrilleros. Por ello, el Che cambia la pregunta de “QQuién lo mató?” por otra, cerrando con un juicio que bien puede retratar al propio autor y a muchos líderes guerrilleros; así dice:

Podríamos mejor preguntarnos: ¿quién liquidó su ser físico? porque la vida de los hombres como él tiene su más allá en el pueblo; no acaba mientras éste no lo ordene. Lo mató el enemigo, lo mató porque quería su muerte, lo mató porque no hay aviones seguros, porque los pilotos no pueden adquirir toda la experiencia necesaria, porque, sobrecargado de trabajo, quería estar en pocas horas en La Habana... y lo mató su carácter. Camilo no medía el peligro, lo utilizaba como una 
diversión, jugaba con él, lo toreaba, lo atraía y lo manejaba; en su mentalidad de guerrillero no podía una nube detener o torcer una línea trazada (Guevara, 1985: 27).

La proximidad discursiva y ritual entre esta postura del Che frente a la muerte de Camilo Cienfuegos y la asumida en 1967 por Fidel Castro ante la noticia de la muerte del Che no parece ser casual. Ahora nos toca agregar una pregunta a partir del martirologio construido: ¿desde el mirador guerrillero quiénes conforman el universo de los muertos y cuál es su función simbólica? El asunto reviste cierta complejidad en la medida en que no hubo un patrón aceptado por los diversos contingentes guerrilleros latinoamericanos. Sin embargo, podemos observar algunas constantes: en primer lugar, el peso simbólico y ritual de los considerados inmortales, hayan sido o no guerrilleros, salvando los campos faccionales de sus adherentes, nos remiten a Marx, Engels, Lenin, Trotski, Stalin o Mao. Este puente abre juego al horizonte de la cultura política de la izquierda latinoamericana, pero se distancia en el modo y contenido de su ceremonialización. Cuentan también los muy latinoamericanos y guerrilleros como el Che, el legendario Sandino y el proteico y resimbolizado Mariátegui. Pero los dos primeros tienen otra entrada: el interesado ocultamiento de sus restos (Tamayo, 1997) 11. El derecho a los restos y a la tumba, pensados como anudados campos de simbolización y ritualización guerrillera, ha fijado los términos de otra confrontación muy simbólica y política, aunque somos conscientes de que su alcance político es mucho más amplio; así lo refrenda el sonado caso de Evita Perón en Argentina. Recordemos otro caso de confrontación sobre restos y tumbas que borra la frontera entre México y Guatemala. Nos referimos a los casos de los comandantes guerrilleros Marco Antonio Yon Sosa, Mario Payeras y de los capitanes Fidel Rascacoj Xitumul y Enrique Cahueque Juárez, cuyos restos y algunos objetos rituales fueron sustraídos en febrero de 1996 y la placa de bronce de su mausoleo colectivo fue robada en noviembre del mismo año12. La significación de la tumba aparece de manera elocuente en las palabras de Yolanda Colom, la esposa de Payeras:

En este caso la tumba también era vida, era solidaridad. En este proceso me fui dando cuenta de que muchas cosas que yo antes

\footnotetext{
11 El gobierno sandinista realizó infructuosos esfuerzos para develar la ubicación de los restos de Sandino, mantenido como preciado secreto de los Somoza. El muy difícil camino de recuperación de los restos del Che, ahora ubicados en Santa Clara, se logró gracias a la ruptura del secreto mantenida por el agente de la CIA Gustavo Villoldo, su enterrador.

12 Seis militantes de la URNG presos desde 1992 en la cárcel de Cerro Hueco conmovidos por tal evento declararon a los medios: "Podrán sacar hasta la última pizca del polvo de sus huesos y convertir sus tumbas en lugares vacíos, pero nunca podrán sacarlos de nuestros corazones ni borrar su ejemplo de lucha y resistencia, ni mucho menos sacarlos de nuestra histórica revolución" (Cerigua, No. 102, noviembre de 1996).
} 
atribuía sólo a gente del pueblo, a gente muy religiosa o con supersticiones, me estaban pasando a mí. A mí que me asumía atea, materialista, a mí que pensaba "un muerto, muerto está". Y estas cosas me hicieron más humana, me hicieron comprender un montón de cosas del comportamiento de la gente. Y también me di cuenta de que estaba embarcada en una locura, en un absurdo si se quiere, pero en un absurdo que no propicié yo sola sino que la gente con su solidaridad, su apoyo, su afecto, su respeto, participó conmigo. Como el pintor que gratuitamente hizo los vitrales o el arquitecto que diseñó la tumba. De alguna manera esta tumba debía significar 'vida' porque por algo la profanaron y la dejaron limpita. No se llevaron los vitrales, que es lo más usual robar para vender. Se llevaron las cenizas de Mario, los objetos, las cositas que los militantes me habían hecho llegar para su tumba, plumas de aves de la selva, piedras de los ríos de la región, hojas, ollitas de barro, hijolitos colorados, semillas de las frutas que comíamos en las hambrunas (Revista del Sur, noviembre de 1997: 2).

Cada panteón guerrillero realiza los propios filtros y ajustes ideológicos y rituales de su jerarquizado martirologio. A ellos se suman los considerados héroes del pueblo, caídos o no en acciones guerrilleras. Un ejemplo, cuando en 1985 fue asesinado Guillermo Quiroz, alias Teacher, el principal dirigente del PC ML de Colombia y de la Unión Nacional de Usuarios Campesinos (ANUC), las unidades guerrilleras locales del EPL dirigidas por el partido participaron en un politizado ritual mortuorio. Un guerrillero dio su testimonio:

Junto con Aníbal Palacio y otros dirigentes regionales, locales y autoridades del lugar, asistimos a los preparativos del entierro. Fue una experiencia muy impactante, pues llegamos de noche y al circular la versión en el pueblo de la presencia de voceros nacionales del partido y del EPL, se concentraron en pocos minutos un millar de pobladores. Nos subimos en un muro y Aníbal habló. Al terminar se hizo silencio; de pronto, todos, me miraron y yo improvisé otro discurso. Al día siguiente el entierro fue majestuoso, se volcó San Jacinto a las calles y vinieron campesinos de lugares cercanos a acompañar el cortejo. Eran cinco mil personas, que en un municipio de ese tamaño es un gran gentío. En medio de banderas, consignas y pujas con los militares terminó el acto con intervenciones de voceros del EPL, de la ANUC y de algunos sindicatos (Cit. por Villarraga y Plazas, 1994: 18). 
Otras organizaciones guerrilleras han optado por un doble anudamiento entre la retórica celebratoria de los caídos en armas y una acción armada de carácter recordatorio. Rememora a contracorriente las imágenes celebratorias del soldado desconocido por las fuerzas castrenses. Lo ilustra Sendero Luminoso al ceremonializar dos fechas luctuosas en homenaje a sus más de trescientos prisioneros muertos por las fuerzas armadas peruanas: en el penal de Lurigancho el 4 de octubre de 1985 (Día del Prisionero de Guerra) y el 19 de junio de 1986 (Día de la Heroicidad) en los penales del Frontón, Lurigancho y Santa Bárbara (mujeres). La segunda conmemoración fue acompañada de una declaración que entre otras cosas asume un eslabonamiento sutil entre una clave sacrificial y otra propia de la mitología del renacer; veámoslo en las palabras del Presidente Gonzalo:

Así, los prisioneros de guerra, como el personaje de la historia, siguen ganando batallas más allá de la muerte, pues viven y combaten en nosotros conquistando nuevas victorias; su recia e imborrable presencia la sentimos palpitante y luminosa enseñándonos hoy, mañana y siempre a dar la vida por el partido y la revolución. ¡Gloria al Día de la Heroicidad! (CC del PC de P, 1989).

\subsection{Las tradiciones del renacer, del no morir y el carnaval}

La ceremonialización de la muerte en el universo guerrillero latinoamericano se constituye, como ya lo hemos podido apreciar, desde una mitología política del renacer de los caídos, cuya persistencia y generalización habla de su eficacia simbólica en los imaginarios sociales en la medida en que se engarza con las tradiciones etnoculturales. Maíz, aquella popularísima canción ayacuchana elaborada en uno de los momentos más álgidos de la guerra interna de los ochenta, retrataba el expandido sentir popular sobre la mitología del renacer colectivo. El compositor Carlos Huamán fue elocuente cuando escribió: "remando en nuestro ataúd, volveremos, volveremos". Lo refrendan muchos otros relatos populares sobre el renacer y deambular del almita del Che en las zonas rurales de Bolivia (Taibo II, 1997: 845-849) o sobre "San Ernesto de la Higuera" como dice otra canción popular. Igualmente, otras figuras menos conocidas a nivel internacional reaparecen en otros relatos procedentes de otros escenarios culturales y otras coyunturas. Dicen los campesinos colombianos a sus pares y a los guerrilleros que por ahí andan Pedro León Arboleda y Camilo Torres en los campos, potenciando un diálogo que cruza los referentes modernos del martirologio guerrillero con los no modernos sobre el retorno o la presencia de los muertitos, muy propios de las culturas populares subalternas. La propia narrativa letrada y militante apela a la hibridación de estas mitologías del renacer del guerrillero. Gabriel Angel, el escritor guerrillero de las FARC, oculto tras su seudónimo de anunciador del Mesías pero también del Juicio 
Final, en su obra La luna del forense ficcionaliza el encuentro entre los combatientes muertos y los vivos. Aclaramos que no pretendemos confundir los planos de lo verosímil del relato literario con lo real, sólo anotar la copresencia de los sentidos fronterizos de esta mitología del renacer. En la obra, el Negro habla desde el más allá por los guerrilleros muertos:

En adelante, cada uno será el espíritu guardián de la región donde cayó. Ustedes van a ayudar a los guerrilleros vivos para que puedan conservar a su lado la pareja que aman. La misión principal es mantener viva la llama de la esperanza en la conciencia de los combatientes, Jefe. Ellos nunca nos verán, pero sentirán nuestra presencia. Lo de la promesa es un favor al que tenemos derecho. Yo voy a ayudar a los guerreros vivos para que nunca les falten los cigarrillitos, mi hermano. Los días en la Franco fueron difíciles (Angel, 2001: 36-37).

Diversos testimonios de líderes y cuadros guerrilleros latinoamericanos han hecho alusión explícita a la presencia en el propio seno de las guerrillas de las tradiciones populares, aun aquellas que, siendo religiosas, transitan entre las representaciones y los rituales de la muerte y las creencias y los rituales de protección de vida.

Contrastan las versiones de los líderes guerrilleros latinoamericanos. Así Héctor Béjar Rivera, del ELN en Perú de 1965, considera al "campesinado peruano, sumamente atrasado, sujeto a antiquísimas creencias y prejuicios. Muchas de estas creencias son conservadoras y negativas para cualquier proceso revolucionario; otras son positivas y pueden ser el germen de una futura evolución política" (Béjar, 1969: 73).

Esta visión de Béjar contrasta con la sostenida por Rolando Morán, del EGP de Guatemala, un decenio más tarde; dice con provocadora heterodoxia: "Hasta ahora, la idea era que el ejercicio del materialismo dialéctico excluye el idealismo. Nosotros pensamos que eso no es así. Lo hemos visto en la práctica, tanto por nuestros compañeros indígenas como por la integración de lo religioso" (Perales,1990: 76).

El doctrinarismo marxista de los líderes guerrilleros cede con respeto frente a las tradiciones culturales de sus bases de apoyo rural indo-mestizas desde los años sesenta. La construcción de sentidos y símbolos asociados a la muerte y la vida, no pueden ser circunscritos a los fueros de la razón moderna, ni a los cartabones ideológicos del marxismo de las direcciones guerrilleras.

Los rituales de protección de vida brindados por los curanderos indígenas y espiritualistas mestizos al comandante guatemalteco Yon Sosa y a los integrantes de su guerrilla varían según da cuenta un testigo presencial. "En otra aldea donde la mayoría eran espiritistas, los campesinos hicieron una 'limpia' al comandante Yon 
Sosa, para protegerlo de los espíritus enemigos" (Gilly, 1986: 79). Decían los pobladores que no lo agarraban a Yon Sosa porque estaba protegido, hasta brujo pensaban que tenía en la guerrilla, que sabía escapar del cerco militar como nagual o convertirse en racimo de guineos (Ídem). Sin lugar a dudas, la recepción cultural del guerrillero va más allá de su prédica ideológica y armada en las poblaciones en que opera. Veamos otro caso. Douglas Bravo, el conocido guerrillero venezolano que estuvo en armas entre 1960 y 1972, rememora su experiencia en la región afromestiza del Norte de Falcón. Douglas narra sus limpias con el brujo Andrés, pero también la recepción de una piedra protectora donada por un brujo de la Portuguesa que lo buscó expresamente. Cuando el mismo Douglas relatas sus diálogos y rituales y además cuenta que "dicen que soy brujo y que estoy ensalmado", nos llevan a repensar la densidad de estos referentes que rebasan los marcos de los rituales de protección de vida. En otro plano, puede apreciarse este diálogo intercultural entre dos hombres de conocimiento, el intelectual tradicional, es decir, el brujo y su par letrado y moderno, quien también sabe por otros medios sobre cómo proteger la vida de los combatientes y la suya propia desde el saber guerrillero. Douglas Bravo recupera algunas de las reiteradas prevenciones brindadas con oportunidad premonitoria por el brujo Andrés; citemos una de ellas:

A nosotros nos impresionaban las facultades del brujo Andrés. Una vez llegó al campamento y me dijo: 'He tenido un presentimiento... soñé que la guerrilla era atacada por fuerzas enemigas'. Hablé con Leonardo Quintana, psicólogo, que no se burlaba de las creencias de los campesinos. Y en ese particular siempre he sido muy respetuoso de las creencias del pueblo. Acordamos, entonces, tomar mayores medidas de vigilancia. En efecto, uno de los destacamentos que estaba situado al oeste del nuestro fue atacado precisamente el día y la hora en el que el brujo Andrés nos había dicho (Peña, 1972: 155).

La quiebra de los rituales de protección que revela la muerte de los guerrilleros ensalmados resulta desmoralizadora, a veces inexplicable. Jaime Bateman, el legendario comandante Pablo del M-19, protegido por las cadenas mentales y de afecto de una activa red de gnósticos liderada por su mamá, alimentó muchos anécdotas y relatos contados por el propio Bateman, los guerrilleros del eme y la gente de sus bases de apoyo. Bateman en una entrevista había dicho:

Lo que pasa en el fondo es que mi mamá es gnóstica, mi mamá fue responsable de la organización de la gnosis en Santa Marta. Y ellos hacen todos los sábados una cadena para protegernos a nosotros, a la organización...Yo no sé si la cadena es o no eficaz. Pero a mí me ha funcionado muy bien...ahí hay algo raro. Yo me siento seguro. Yo he 
estado en situaciones muy difíciles, muy desesperadas... Y nada, hermano, ahí sigo (Molano, 1983: 1).

Un fatal accidente aéreo sobre el Darién rumbo a Panamá acabó con la cadena de protección y la vida de Jaime Bateman. Como sostiene una de las más penetrantes crónicas de la guerrilla colombiana: "Con su muerte quedaba a oscuras no sólo Fayad -el relevo en el mando del M 19 [RM]-, sino todo el M-19” (Restrepo, 1986: 37).

Al desplazarse el sentido ideológico-político desde el cual se asume la muerte hacia la recepción concreta de los compañeros caídos, se abre un abanico de sentidos no siempre explícitos. El diario del Che y muchas otras memorias y crónicas de los guerrilleros latinoamericanos dejan evidencia de que la elaboración individual y colectiva de la pérdida y duelo frente a un combatiente caído reviste cierta complejidad.

Algunas guerrillas como el EPL colombiano a fines de los setenta asumía la tradición de recuperar los cadáveres de sus combatientes, no sólo por el prurito de cumplir un ritual político-mortuorio o, como creía el ejército, para velar las identidades de sus integrantes y los costos reales de sus pérdidas. En realidad, había una fundada elaboración simbólica de reintegrar al combatiente a sus filas y elevar la moral de la unidad guerrillera. El proceso ritual de rendir honores y enterrar al guerrillero abría juego a su renacer simbólico tras la reapropiación de su nombre y/o seudónimo por alguno de los sobrevivientes, así como sus renovadas virtudes de combatiente heroico13. El propio Marcos en 1994 recordaba que su nombre tenía simbólica deuda con un compañero mayor, un desaparecido guerrillero mexicano a quien conoció y apreció por sus enseñanzas. Un nombre de relevo supone acaso los sentidos de emular, recordar y renacer y su carga es mayor si hay lazos de parentesco o de pareja. Minerva Armendáriz, la guerrillera del MAR en México, relata que eligió Karla como nombre de combate en sentido homenaje a Carlos, su hermano muerto en acción de armas (Armendáriz, 200: 15). No resulta diferente la acción simbólica de renombrar a las unidades de combate y a los frentes guerrilleros con los nombres de los héroes guerrilleros regionales, ni convertir anualmente ciertas acciones de combate en celebratorias de los mismos.

Desde otros miradores guerrilleros, la mayor o menor elaboración política y simbólica de las pérdidas significativas puede afectar a los sobrevivientes. Omar Cabezas narra de manera descarnada el efecto duro de la pérdida de un respetado mando guerrillero sandinista:

Te voy a contar lo que yo sentí cuando oí la noticia de que Tello había muerto: sentí miedo cuando Tello murió. Sentí miedo porque a Tello

${ }_{13}$ Comunicación personal de N3, excomandante del EPL, México, 24 de junio de 2002. 
yo me lo había copiado en alguna medida; me había enseñado a caer, las posiciones de tendido, me había enseñado qué hacer cuando llegara la Guardia, qué hacer cuando la Guardia se fuera acercando... Y de repente, el hombre que cae es Tello, el que me enseñó todo. ...Hubo momentos en que pensé: todo lo que me enseñó no sirve... Qué ganamos con sus enseñanzas si lo matan a él primerito, ni siquiera matan a un compañero de los que nos entrenamos juntos, pues entonces hubiéramos podido decir: no asimiló los conocimientos que nos enseñó Tello (Cabezas, 1982: 160).

Si la muerte opera como un símbolo dominante para el movimiento guerrillero es por su asociación a un valor de alta densidad política y simbólica como la patria o la tierra adjetivadas, la soñada patria socialista, la imaginada autonomía y territorialidad étnica, la ciudad reinventada, la carnavalizada fábrica o mina. Todas ellas operan como algo más que ideas-fuerza; el pathos revolucionario que las acompaña se nutre de sus símbolos y de sus modos de asumir el principioesperanza como lo diría Marc Bloch. De cara al principio-esperanza, la muerte del guerrillero queda resituada en su dimensión sacrificial como una posibilidad y como un deber deseable cargado de positividad. La preciada vida y la sangre son los dones que los miembros de la colectividad guerrillera desean entregar en el ritual del combate, más que en ninguna otra acción prevista o accidental frente al enemigo. No hay relato guerrillero que no esté cargado de esa imagen voluntarista y sacrificial que eslabona los sentidos de sus penurias cotidianas, sus hambres, sus heridas, sus enfermedades y su propia muerte con la idea del renacer. La propia representación del hombre nuevo es prístina cuando Omar Cabezas, el guerrillero sandinista, escribe en campaña:

El hombre nuevo empieza a nacer con hongos, con los pies agusanados, el hombre nuevo empieza a nacer picado de zancudos, el hombre nuevo empieza a nacer hediondo. Esa es la parte de afuera, porque por dentro, a fuerza de golpes violentos todos los días, viene naciendo el hombre con la frescura de la montaña... (Cabezas, 1982: 119).

La presencia de la mitología del renacer ha sido reseñada por su importancia en el ritual de pasaje de escuelante a guerrillero en una de la escuela de combatientes del ELN de Colombia (Cárdenas y Duarte, s/f). Por ello, no son gratuitos los gritos de orden reinantes entre los fines de los cincuenta y principios de los sesenta que hacen de la muerte un deseado valor sacrificial al mismo tiempo que sugiere la posibilidad del viaje y/o del nacimiento del héroe: “¡Patria o muerte!, ¡venceremos!” de los guerrilleros del Movimiento 26 de Julio en Cuba y el “¡Tierra o 
Muerte! ¡Venceremos!” de los guerrilleros del Frente de Izquierda Revolucionaria en Perú. La voz de orden sandinista de los años setenta va en la misma dirección que las anteriores: “¡Patria libre o morir!” o la añeja consigna de “¡Liberación o Muerte!” del ELN de Colombia. Por último, la retórica del retorno de la muerte con que se presentaron los del EZLN en su única gran acción de armas del EZLN en 1994, no parece muy distante de esta resemantización política de la muerte; los zapatistas dicen venir de la muerte para seguir siendo.

La distancia se expresa en la búsqueda de este grupo alzado en armas que no busca el combate, la acción de armas, el más letal medio de ritualizar la muerte, pero que sabe de la muerte real y simbólica. Las voces de orden que movilizan el sentido de la muerte se traducen tácticamente en la búsqueda de diversos modos de combate; donde la sorpresa, la ventaja y el límite de la acción deberían quedar idealmente del lado guerrillero, la historia real es más compleja, los reveses pesan como plomo. La retórica de la muerte en las organizaciones guerrilleras ha tenido notas y experiencias próximas a las del EZLN. Así la ORPA guatemalteca recupera el tiempo del no combate como deseable y posible; en cierta manera, es una forma de carnavalizar la propia lógica de la guerrilla de la muerte a la vida, del desgaste a la acumulación de fuerzas; así dicen:

Se ha dicho con demasiada frecuencia y seguridad que 'la guerrilla que no combate no puede subsistir y mucho menos ampliarse'. Esta posición, que había adquirido carácter de dogma, ha sido desmentida por los ocho años de preparación en los que nuestra organización no disparó un solo tiro (Perales, 1990: 48).

Cerremos nuestra última ventana al universo guerrillero y con él nuestro texto, con dos referentes polares. El primero alude a una de las caras más duras de la muerte en la cultura guerrillera; nos referimos a los ajustes de cuentas, comprensibles unos en aras de la supervivencia del colectivo, sin coartada, y coherencia en otros. El segundo, alusivo a los caminos guerrilleros del carnaval, es decir, la otra cara de la subversión de los órdenes en la retórica y la acción ligadas a las representaciones de la vida y la muerte.

Los ajustes de cuentas dentro del movimiento guerrillero con los disidentes, desertores, infiltrados y traidores pasan la mayoría de las veces por la lógica de las armas, que no es necesariamente la lógica de la política. La yuxtaposición o confluencia de la tradición estalinista, la disciplina guerrillera, aunadas a las más añejas sedimentaciones culturales autoritarias, potenciaron esta lógica autodepredatoria intra-guerrillera. Muchas de esas muertes son objeto devalorativo, una excrecencia guerrillera.

En la cultura política de la izquierda colombiana el apelativo de "sapo", marca al infiltrado o informante como un ser despreciable en el seno de la guerrilla o en las 
bases de apoyo o su radio y redes más amplias. En la guerrilla, la práctica de ajusticiar "sapos" está consensuada y legitimada, análogo trato recibe el informante guerrillero que opera en el seno de las fuerzas del orden o en su entorno. La presunción de traición en muchos casos tiene desenlaces fatales; pareciera que no hubiera tiempos para la investigación y el juicio justo. La lógica militar se impone a la política; así también los campos de la disidencia, el incumplimiento, la baja y la transferencia revelan cuotas significativas de arbitrariedad, pero que no son muy distintas a las que prevalecen en las instituciones castrenses al servicio del Estado. El ejercicio de la violencia en cierto sentido se vuelve contra sus cultores y es que la guerrilla debe sobrevivir a los acosos externos y eternos, lo cual endurece la conducta de sus mandos y muchas veces la complicidad de los demás. El caso de Roque Dalton es elocuente, pero no el único. Hay un caso extremo en la historia de las guerrillas latinoamericanas, que convierte a la disidencia colectiva en traición y masacre. Es el sonado caso internacional de la muerte de 164 integrantes de una facción disidente del frente guerrillero Ricardo Franco de las FARC en la región del Cauca, acusados y sancionados por su máxima jefatura, Javier Delgado, de ser "mercenarios" y "asesinos del pueblo" (Villarraga y Plazas, 1994: 192). Hay otro más muy sonado internacionalmente, el asesinato de la Comandante Ana María y el suicidio del Comandante Marcial en las guerrillas salvadoreñas. Los otros ajustes de cuentas pasan inadvertidos en los grandes relatos de la historia guerrillera de América Latina como si no contaran para explicar su universo. Pero, claro, los usos de los ajustes de cuentas como los ajusticiamientos de la mala clase en el seno del pueblo no escapan a los usos de la guerra psicológica promovidos por las fuerzas del orden en tiempos de guerra interna. Un comandante del FMLM, refiriéndose a los segundos, antepone la recepción popular de los mismos en términos autocríticos:

...en la época de ORDEN - grupo paramilitar que operaba en 1970 [RM]- nosotros, a mi modo de ver cometimos errores en lo que dice relacionado con el tratamiento dado a los miembros de las bandas paramilitares. Esto tuvo repercusiones negativas más tarde. En ese tiempo, los compañeros organizados llegaban a los cantones, sacaban a los hombres detectados como pertenecientes a ORDEN y frente a su familia los ajusticiaban. A causa de esto, en muchas zonas la población empezó a vernos como enemigos. Pero esa experiencia nos hizo reflexionar y nos dimos cuenta que mucha gente estaba ahí por miedo, reclutada a la fuerza y no estaba ganada por la causa de la oligarquía. Según mi criterio, todo eso se explica, precisamente, porque no habíamos estudiado a fondo el fenómeno, porque desconocíamos al enemigo (Harnecker y Perales, 1990: 136). 
Veamos ahora nuestro cierre carnavalesco. La carnavalización de la muerte puede ser reconciliada con el campo celebratorio del martirologio guerrillero, según podemos verlo a través de una exitosa experiencia de los Tupamaros en Uruguay, una de las más importantes guerrillas urbanas del continente. El MLNT se abocó a preparar un evento espectacular en homenaje al Che Guevara el 8 de octubre de 1969, el cual, al mismo tiempo, debería alcanzar fines más concretos de propaganda armada y obtención de recursos materiales.

El Che, al cumplirse el segundo aniversario de su muerte, había ingresado al martirologio de la nueva izquierda latinoamericana y los convencionales ritualismos conmemorativos. Pero los Tupamaros prefirieron celebrarlo de otra manera. Lo hicieron a través de la exitosa toma de la pequeña ciudad de Pando, de cincuenta mil habitantes y ubicada a 30 kilómetros de Montevideo (Labrousse, 1971: 135). Los objetivos particulares consistían en el copamiento y asalto de la comisaría, el cuartelillo de bomberos, la central telefónica y tres bancos. La unidad encargada de la operación movilizó a 49 cuadros armados distribuidos en seis comandos. El despliegue de las unidades tupamaras se realizó bajo la cobertura de un fingido y bien montado cortejo fúnebre que llevaría los restos de un pariente muerto en Buenos Aires repatriado para efectos de enterrarlo en el panteón familiar del Cementerio de Soca. El 8 de octubre a las 10 de la mañana, nueve familiares y un "cura" llegaron a la funeraria contratada en Montevideo, portando la urna y las ofrendas florales. Se distribuyeron en cinco coches además de la carroza fúnebre, y avisaron al encargado de la funeraria que en el kilómetro 36.5 serán recogidos diez familiares y así lo hicieron. Se sumó al cortejo una camioneta combi. En el kilómetro 40, fueron reducidos los siete empleados de la funeraria. Después de salvar algunos problemas de coordinación y logística, lograron alcanzar con éxito sus seis objetivos -aunque llegando casi a Montevideo- la guerrilla fue alcanzada por las fuerzas del orden y sufrió varias bajas (MLNT, 1971: 137-178; Labrousse, 1971: 135-140). El recordatorio de la muerte del Che ensanchó el martirologio tupamaro con los caídos en la Operación Pando, mientras por otro lado reveló las limitaciones de operar fuera de Montevideo aun en poblaciones cercanas.

Pero el carnaval guerrillero en sus marcos lúdicos y festivos de las fiestas pueblerinas y campamentos guerrilleros no debe ser olvidado aunque prescindamos de su ejemplificación. En lo que concierne a la retórica guerrillera, Jaime Bateman, desde el M-19, ha dejado una copiosa cantidad de relatos sobre la manera en hacer del accionar guerrillero y revolucionario una fiesta (Restrepo, 1986: 38), acaso una manera lúdica y celebratoria de la vida. Con otros tonos y desde nuestro mirador mexicano, Marcos, el subcomandante, prefiere carnavalizar la muerte y a un mes de la rebelión zapatista declara a la corresponsal Blanche Pietrich lo siguiente: 
(la muerte) Para nosotros es vida, en esa lógica tan absurda de una muerte cotidiana que se hizo normal en estas situaciones. Es vivir pues, es una alegría. Cuando cumplimos un mes de que empezara la guerra se hizo fiesta para recordar a los compañeros que murieron. Decían: es que su muerte la vemos con alegría porque es vida para otros, en ese lenguaje tan críptico, pero tan rico al mismo tiempo. La muerte pues, como gozne entre dos épocas, como disputa por la soberanía y el destino y como semilla de la vida nueva. Pero no como apología de la violencia ni como terrorismo, sino como lucha contra la política que es muerte, por eso frente al combate han hecho política (La Jornada, 6 de febrero de 1994).

Diremos, por último y a manera de cierre, que el carnaval afecta el propio saber sobre la guerrilla latinoamericana en el que nos hemos involucrado, por acartonadamente serio, por quemante de muerte y violencia elusivas o descarnadas, por juicios fáciles y conceptos evanescentes. Por todo ello, olvidémonos carnavalescamente de las conclusiones para abrir juego al postergado diálogo sobre lo políticamente nombrable y lo culturalmente sumergido o viceversa.

\section{Bibliografía}

Arendt, H. (1970): Sobre la violencia. México, Cuadernos de Joaquín Mortiz.

Aricó, J. (1999): Entrevistas 1974-1991. Córdoba, Ediciones del Centro de Estudios Avanzados de la Universidad Nacional de Córdoba.

Armendáriz Ponce, M. (2001): Morir de sed junto a la fuente. Sierra de Chihuahua 1968. Testimonio, Universidad Obrera de México.

Attiná, F. (1981): “Guerrilla”, en Bobbio, N. y N. Matteucci, Diccionario de Política, vol.1. México, Siglo XXI Editores, pp. 769-771.

Béjar Rivera, H. (1969): Perú 1965: Una experiencia libertadora en América. México, Siglo XXI.

Blanco, H. (1972): Tierra o muerte. Las luchas campesinas en Perú. México, Siglo XXI.

Cabezas, 0. (1982): La montaña es algo más que una inmensa estepa verde. México, Siglo XXI. 
Cárdenas, C. y C. Duarte (s/f): Fusiles de madera. Disponible en web: http://www.antropologiavisual.cl/

Castañeda, J. G. (1993): La utopía desarmada. México, Joaquín Mortiz.

Chartier, R. (1999): El mundo como representación. Historia cultural: entre práctica y representación. Barcelona, Gedisa editorial.

Chevalier, J. y A. Gheerbrandt (1999): Diccionario de los Símbolos. Barcelona, Herder.

Ejército de Chile (2000): Apreciación Combinada de la situación subversiva en el Continente, XXIV Conferencia de Ejércitos Americanos 2000-2001 (secreto).

Fanon, F. (1963): Los condenados de la tierra. México, Fondo de Cultura Económica.

FARC (2002): "La cultura guerrillera es cultura popular", Resistencia, 29, pp. 1-4. Disponible en web:

http:/www.FARC-ep.org./Revista/Resistencia29/Web/cultura.html

Gabriel, A. (2000): La luna del forense. Santa Fe de Bogotá, Ediciones Magdalena Medio Internacional.

Garrido, L. (1997): "Desde Guatemala Eternamente Yolanda”, Revista del Sur, 73, 2 pp. Disponible en web: http://www.revistadelsur.org.uy/revista.073/central.html

Gilly, A. (1986): La senda de la guerrilla. Por todos los caminos 2. México, Editorial Nueva Imagen.

Guevara, E. (1977): Escritos y discursos 3. La Habana, Editorial de Ciencias Sociales.

Guevara, E. (1985): La Guerra de Guerrillas. La Habana, Editorial de Ciencias Sociales.

Guthmann, G. (1991): Los saberes de la violencia y la violencia de los saberes. Montevideo, Nordan Comunidad.

Guzmán Campos, G.; O. Fals Borda y E. Umaña Luna (1962): La violencia en Colombia. Bogotá, Editorial Punta de Lanza.

Hernández, A. (2001): La muerte de Rubén Jaramillo y la paranoia anticomunista del régimen de López Mateos 1960-1963. Tesis de maestría en Historia Contemporánea, 
Instituto de Ciencias de la Educación de la Universidad Autónoma del Estado de Morelos, Cuernavaca.

Labrousse, A. (1971): Los Tupamaros. Guerrilla urbana en el Uruguay. Buenos Aires, Editorial Tiempo Contemporáneo.

Marcuse, H. (1968): El fin de la utopía. México, Siglo XXI.

Molano, A. (1983): Cuando Jaime Bateman habló de su muerte, SPI. México, multicopiado por simpatizantes del M-19 (publicado originalmente en La Semana de Colombia), 2 pp.

Montiel, E. (1985): "7 señales en el accidentado sendero de la democracia peruana", Nuestra América, 13, Centro Coordinador y Difusor de Estudios Latinoamericanos de la UNAM, pp.75-89.

Moore, B. (1989): La injusticia: bases sociales de la obediencia y la rebelión. México, Instituto de Investigaciones Sociales de la UNAM.

MLNT (1971): Actas Tupamaras, Buenos Aires, Sahpire editor.

Montemayor, C. (1994): La guerra en el paraíso. México, Editorial Diana.

Payeras, M. (1981): Los días de la Selva. México, Escuela Nacional de Antropología e Historia.

Peña, A. (1972): Conversaciones con Douglas Bravo. Caracas, Editorial Ateneo.

Perales, I. (1990): Guatemala Insurrecta (Entrevista con el Comandante en jefe del Ejército Guerrillero de los Pobres). Madrid, Editorial Revolución.

Piretz, P. T. (1988): “Gorilismo", en S. del Campo (coord.), Diccionario UNESCO de Ciencias Sociales II. Barcelona, Planeta-Agostini, pp. 959-960.

Presidente Gonzalo (1987): ¡Día de la heroicidad! Dar la vida por el partido y la Revolución. Reproducido por el Comité Central del Partido Comunista del Perú, Tercer Aniversario (junio de 1989). Disponible en web: http://www.maoism.org/misc/peru/doh/spanish/heroismo15.htm

RAE (2001): “Guerrilla”, en Diccionario. Disponible en web: http://www.rae.es/ 
Rama, C. (1988): “Guerrilla (erismo)", en S. del Campo (coord.), Diccionario UNESCO de Ciencias Sociales II, Barcelona, Planeta-Agostini, pp. 979-981.

Ratner, M. y M. S. Smith (comps.) (1997): El Che Guevara y el FBI. El expediente de la policía política de Estados Unidos sobre el revolucionario latinoamericano. México, Siglo XXI.

Restrepo, L. (1986): Historia de una traición. Bogotá, Plaza \& Janes.

Romualdo, A. (1974): "Canto Coral a Túpac Amaru qué es la libertad”, en J. Ortega, Realidad Nacional II. Lima, Retablo de Papel Ediciones, pp. 329-330.

Sandoval, A. M. (1999): "El mito y sus hibridaciones como soporte literario del testimonio", en M. R. Morales, Señores bajo los árboles. Departamento de Español y portugués de la Universidad de Iowa, 9(2).

Sorel, G. (1935): Reflexiones sobre la violencia. Santiago de Chile, Editorial Ercilla.

Sarlo, B. (1998): “Mayo 68/mayo 98. Tríptico revolucionario", La Nación (Buenos Aires, abril 12. Disponible en web: www.literatura.org.

Taibo II, P. I. (1997): Ernesto Guevara también conocido como El Che. México, Grupo Editorial Planeta.

Tamayo, J. A. (1997): “Yo enterré al Che”, en El Nuevo Herald, 21 de septiembre.

Villarraga, Á. y N. Plazas (1994): Para reconstruir los sueños (una historia del EPL). Bogotá, Colcultura-Fundación Progresar-Fundación Cultura Democrática.

Villaveces, S. (1996): "La invisibilidad de la violencia", Utopías http://www.upaz.edu.uy/procesos/panamerica/colomb/invisb.htm.

Watson, P. (1982): Guerra, persona y destrucción. Usos militares de la psiquiatría y la psicología. México, Nueva Imagen. 